\title{
The transformation of the German vocational training regime: evidence from firms' training behaviour
}

\author{
Marius R. Busemeyer, Renate Neubäumer, \\ Harald Pfeifer and Felix Wenzelmann
}

\begin{abstract}
The German system of industrial relations has undergone significant changes in the last decade. This article reflects on and provides empirical evidence for how these changes have affected the training behaviour of firms. Conventional perspectives would predict a general decline in training investment when the constraints of collective wage bargaining are loosened. Relying on a large data set on the costs and benefits of apprenticeship training for the years 2000 and 2007, we do find evidence for this hypothesis but would add that the strength of the effect varies strongly across different types of firms. Large firms have benefited much more from participating in training than have small firms and have therefore maintained their investment in training because they are able to reduce net costs by expanding the productive contributions of apprentices. This finding may help to explain the apparent resilience of the German training system in the recent economic and financial crisis.
\end{abstract}

\section{INTRODUCTION}

In the last decade, the German political economy has undergone significant policy changes in industrial relations, the welfare state and the labour market (Streeck, 2009; Trampusch, 2009a). The decentralisation of collective wage bargaining has manifested as a general decline in the coverage of wage bargaining agreements, as well as an increase in their 'internal flexibility', meaning the leeway they offer firms to complement and/or replace collective agreements at the sectoral level with localised, firm-based agreements (Casey et al., 2012; Gumbrell-McCormick and Hyman, 2006; Menz, 2005; Schmierl, 2001; Silvia and Schroeder, 2007; Streeck, 2009). The spread of local and firm-based 'pacts for employment and competiveness' has been so extensive that this development could be regarded as a 'paradigm shift in the German system of industrial relations' (Seifert and Massa-Wirth, 2005: 237). What is more, the collective

Marius R. Busemeyer is Professor of Political Science, University of Konstanz, Renate Neubäumer is Professor of Economics, University of Koblenz-Landau and Harald Pfeifer and Felix Wenzelmann are Researchers from the Federal Institute for Vocational Education and Training (BIBB), Bonn. Correspondence should be addressed to Marius R. Busemeyer, University of Konstanz, PO Box 79, Konstanz 78457, Germany; email: marius.busemeyer@uni-konstanz.de 
actors central to the German system of industrial relations are witnessing the ongoing erosion of their membership. Triggered largely by the developments in East Germany after unification, employers' associations have to cope with individual employers who are resistant to the constraints of collective wage agreements (Silvia and Schroeder, 2007). Trade union membership is declining in real numbers, and union members are aging (Hassel, 1999). The decentralisation of the institutions of collective wage bargaining is thus accompanied and reinforced by a process of 'disorganization' (Höpner, 2007) among collective actors, which results in the particularistic interests of individual unions and/or employers having increasing dominance over collective concerns. The recent strike by the professional union of German train drivers is a very concrete - though still exceptional-indication of this general trend (Hoffmann and Schmidt, 2009).

What has not been studied extensively so far are the implications of these recent changes for the German vocational education and training (VET) system. Scholarship in the tradition of the 'varieties of capitalism' school of thought (Hall and Soskice, 2001) emphasises the strong institutional complementarities between industrial relations, collective wage bargaining and vocational training (Bosch and Charest, 2008). The notion of 'beneficial constraints' originally coined by Streeck $(1989 ; 1994)$ implies that a well-developed and robust system of industrial relations and collective wage bargaining is an important precondition for triggering employer investment in transferable vocational skills. The lack of a framework of collective institutions in liberal market economies such as the UK is traditionally regarded as an explanation for employers' limited willingness to provide training in occupational skills that are relevant beyond the immediate firm-specific context (Finegold and Soskice, 1988; Lane, 1990). In the field of labour market economics, the model developed by Acemoglu and Pischke $(1998 ; 1999)$ makes a very similar prediction: the institutional constraints of collective wage bargaining institutions set incentives for employers to invest in skills.

But what happens when these constraints are increasingly loosened? Will employers stop investing in vocational training? Or do employers maintain their general commitment to training but adjust their training strategies to reflect the new constraints and opportunities of the more decentralised system of industrial relations? Recent work studying the process of change in the institutional framework of German VET shows how the transformation of the political economy interacts with and conditions processes of institutional change and reconfiguration in the vocational training system (Bosch, 2010; Busemeyer, 2009a; 2009b; 2009c; 2012; Hassel, 2007; Thelen and Busemeyer, 2008; 2012; Thelen, 2004; 2007; Trampusch, 2009b; 2010). The central finding of this literature is that the German vocational training system is indeed undergoing a process of significant change. This process unfolds in an incremental manner, however, and thus may not be immediately noticeable. The changes are taking place in the same direction as those happening in industrial relations: the vocational training system is becoming more flexible and differentiated, allowing for more firm-specific approaches and solutions to the problem of skill formation. Concrete examples of changes in the VET system are the increasing room for firm-specific implementations of nationally recognised and certified training profiles, the differentiation of the system through the creation of new levels of apprenticeship below and above the traditional level of skilled worker and the liberalisation and deregulation of regulatory policies such as those that govern how training personnel are trained (Busemeyer, 2009c: 203). 
Adding to this line of work, which is mostly concerned with the macro level of policy making, the present article studies the implications of changes in the German political economy at the micro level of firm behaviour. The empirical basis for the article comes from two large-scale surveys on the costs and benefits of apprenticeship training in German firms that were conducted by the German Federal Institute for Vocational Education and Training (BIBB Bundesinstitut für Berufsbildung). By pooling observations from the two survey waves in 2000 and 2007, we have been able to analyse how a number of training and other labour market reforms enacted during the crucial reform period of 2003-05 (which was also the period when significant reforms were made to welfare state and labour market policies as part of the 'Agenda 2010') affected the relative benefits and costs of apprenticeship training. Our main findings demonstrate that large firms have benefited from the recent flexibilisation of the training system to a significantly greater extent than smaller firms have. This, in turn, has allowed large firms to remain committed to the system and to largely maintain their previous levels of investment in training. Our findings thus resonate very well with recent arguments about the institutional changes in the German training system from a collectivist to a more segmentalist variety (Thelen and Busemeyer, 2008; 2012).

The remainder of the article is structured as follows: first, we discuss linkages between the training behaviour of firms at the micro level and institutional contexts at the macro level, in particular labour market structure, the role of collective wage bargaining and the regulatory framework of vocational training. Second, we provide some descriptive statistics on the development of training costs in German firms, comparing the years 2000 and 2007. Third, we engage in a multivariate regression analysis to probe the relationship between changes in firms' training strategies (indicated by net costs and benefits of training) and the institutional context. The fourth section concludes by discussing the implications of our findings for the future viability of the German training system.

\section{LITERATURE REVIEW AND THEORY}

Scholars in labour market economics have long puzzled over the functioning and viability of the German vocational training system (Franz and Soskice, 1995; Harhoff and Kane, 1997; Kempf, 1985; Neubäumer, 1999). German firms incur significant net costs when investing in training as this training often entails significant transferable skills. This behaviour is 'irrational' from the perspective of human capital theory (Becker, 1993) because firms should only be willing to finance training in specific skills.

The pertinent literature in economics provides several explanations for this puzzle, such as information asymmetries (Franz and Soskice, 1995; Katz and Ziderman, 1990), ex ante uncertainty (Alewell, 1997; 1998; Hashimoto, 1981; Stevens, 1994) and complementarity of general and specific human capital (Feuer et al., 1991; Franz and Soskice, 1995; Neubäumer, 1999). Acemoglu and Pischke (1998; 1999) have integrated the different explanations into one model and underlined the importance for the functioning of the German vocational training system of labour market 'imperfections' (i.e. institutions) that promote wage compression.

According to Acemoglu and Pischke (1999: F124-F125), the strong compression of wages has several beneficial effects on the training behaviour of firms. First, it lowers the incentives for apprenticeship graduates to leave the training firm to employ their transferable skills at another firm. Second, when wage compression is enforced via 
collective wage bargaining, it also reduces the possibility of poaching because the ability of competing firms to offer higher wages to apprenticeship graduates is constrained (independent of the fact that competing firms might be reluctant to hire apprenticeship graduates of another firm because of information asymmetries). Third, when complemented by strong employment protection, wage compression forces firms to pay wages to less skilled workers above their productivity level. Hence, firms have an incentive to invest in the training of low-skilled workers in order to increase their productivity (Streeck, 1989; 1994; 2004). Fourth, training firms can recoup a part of their training investments afterwards because wage compression allows them to employ highly skilled workers at wage levels below their productivity. In a fully competitive market, by contrast, wages would simply reflect differences in productivity levels. Firms may actually have an interest in maintaining wage compression because it depresses the wages of the highly skilled (see Hassel and Rehder, 2001 for a similar argument).

In sum, according to Acemoglu and Pischke (1998; 1999), firms invest in training in order to secure their future supply of skilled workers (the so-called 'investment model', cf. Merrilees, 1983). However, firms' decisions to participate in training may also follow the logic of the 'production model' (Lindley, 1975): studies on the training systems in Germany and especially Switzerland have found that for many firms (particularly in occupations requiring training), participating in apprenticeship training does not result in net costs and may in fact yield concrete economic benefits during the period of training (Beicht et al., 2004; Dionisius et al., 2009; Schönfeld et al., 2010; Wolter, 2008). This is because in addition to learning a trade, apprentices contribute to the production process by taking over some of the tasks usually performed by semi-skilled or even skilled workers without their being paid skilled wages. This so-called 'production model' or 'substitution model' (in contrast to the 'investment model') dominates in training for manual occupations with low skill content and/or in small firms in which the benefits of apprentices taking over the tasks of skilled workers are larger (e.g. apprentices selling bread in a bakery) (Neubäumer, 1999; Neubäumer and Bellmann, 1999). Firms thus are motivated to offer apprenticeship training in order make use of apprentices in the production process. As a consequence, and because real investments in skill formation are low, firms do not aim to retain their apprentices (Mohrenweiser and Backes-Gellner, 2010).

In reality, of course, the 'investment model' and the 'production model' are ideal types. For most firms, the motivation to offer apprenticeship training is a mix of ensuring the future supply of skilled workers and hiring cheap labour. Taking the rate of retention of apprenticeship graduates as the core indicator, Mohrenweiser and Backes-Gellner (2010) found that about 44 per cent of German firms in 2003 followed a pure investment strategy (i.e. retained almost all apprentices), whereas 18.5 per cent followed a substitution strategy and did not retain any apprentices. Their results also imply that about 40 per cent of German firms participate in training with 'mixed models', that is, both because they value the productive contributions of apprentices and because they aim to secure their future supply of skilled workers. ${ }^{1}$

\footnotetext{
${ }^{1}$ Using slightly different definitions and a different data set, we find a higher share of firms training according to the production model (c. 40 per cent) and a lower share of firms with a 'mixed model' ( 25 per cent); see later section and Table A2 in the appendix for details.
} 
Complementing the perspective of economics, scholarship in labour market sociology has long been concerned with the analysis of labour market 'imperfections'. The theory of the 'tripartite labor market' (Lutz and Sengenberger, 1974; Sengenberger 1978; 1987; Toft, 2004) has been particularly influential in the analysis of the German training system because it was able to explain the existence and sustainability of a third kind of labour market - the occupational labour market - alongside internal and external labour markets and to illuminate the connections between labour market institutions and employer strategies to invest in training. Business associations and institutions such as the German Chambers of Industry and Commerce and collective industrial relations are crucial components of an overarching institutional framework that helps individual firms in a given economic sector to overcome collective action problems in training decisions. Vocational certificates are important in that they delineate the boundaries of occupational labour markets and ensure the portability of skills learned during the apprenticeship. Thus, there is a complementarity between occupational labour markets and the 'production model' of training investment because apprentices' willingness to contribute to the production process hinges on their belief that they will be able to find work as a skilled worker with another employer after the end of their training period. Conversely, the 'investment model' corresponds to personnel strategies centred on internal labour markets because employers will only be willing to invest in transferable vocational skills when apprenticeship graduates are likely to stay with the firm (see also Marsden and Ryan, 1990).

A significant weakness of this kind of scholarship is its static nature: studies are mostly concerned with explaining cross-sectional differences in training strategies between different kinds of firms, economic sectors or countries. What is missing is a systematic analysis of the effects of changes over time, in particular how changes in the socio-economic context interact with firms' training decisions. This issue is discussed in the section that follows.

\section{CHANGES IN THE GERMAN POLITICAL ECONOMY AND THEIR EFFECT ON TRAINING}

The central aim of this article is to study how recent changes in the German political economy have affected firms' training behaviour, specifically the extent of their investment in training. Of primary importance for this behaviour are the transformations that have occurred in two institutional spheres: labour market institutions (primarily collective wage bargaining), on the one hand, and the regulatory framework of vocational training itself, on the other.

The framework developed by Acemoglu and Pischke (1998; 1999; 2000) yields clear hypotheses on how changes in collective wage bargaining arrangements affect the training behaviour of firms. The most important effect of the erosion of collective wage bargaining arrangements is an increase in wage dispersion ${ }^{2}$ (Dustmann et al., 2009; Gernandt and Pfeiffer, 2006; Kohn, 2006). The erosion of collective wage bargaining implies that wages reflect differences in productivity more strongly than

\footnotetext{
${ }^{2}$ Dustmann et al. (2009) found that between 1995 and 2004, de-unionisation in Germany can explain nearly one-third of the increase in wage inequality between unskilled workers and employees with a vocational training certificate.
} 
before. This, in turn, leads to a lowering of wages for the less skilled but might also contribute to an increase in wages for the highly skilled so that the wage differential between a skilled and unskilled worker increases. If we look at this development through the prism of the 'investment model', the paradoxical effect is that the relative returns of firm investment in VET decrease because firms are less able to recoup training costs by paying lower wages to high productivity workers.

Thus, firms pursuing an investment strategy - training for either an internal or occupational labour market - are less willing to invest in skill formation. Building on Acemoglu and Pischke (1998; 1999; 2000), we would generally expect the erosion of collective wage bargaining to affect training behaviour by causing firms to withdraw en masse from offering apprenticeship training and to be less willing to incur the costs of training. In sum, the model would predict a general shift from the investment model to the production model.

Furthermore, based on the literature on the 'production model' and labour market segmentation cited earlier, it could also be argued that the general flexibilisation of the wage bargaining system, complemented and supported by an incremental flexibilisation and differentiation of the regulative framework of vocational training itself (Busemeyer, 2009a; 2009b; 2009c; 2012; Thelen, 2004; 2007; Thelen and Busemeyer, 2008 ; 2012), lowers the costs of apprentices to firms and thus increases firms' willingness to hire them. This is first of all because the erosion of collective wage bargaining can directly reduce costs in terms of apprentices' wages. The subsequent decline in apprentices' wages and the increased flexibility for firm-specific skill provision in the training itself could then cause the productive contributions of apprentices to increase. At first sight, we would thus also expect a general turn from the investment to the production model. The crucial argument in Thelen and Busemeyer (2008; 2012), however, is that different kinds of firms react differently to the changing environment because their training strategies are linked to different kinds of labour markets. Large firms are expected to benefit more than small firms from the more flexible system.

The empirical analysis addresses the following questions: first, can we identify significant changes in the training behaviour of firms between the years 2000 and 2007? And if yes, does this signal a general move away from the investment model towards the production model? Given the nature of the data, we can not trace the impact of specific reforms or institutional changes on training behaviour directly, but we can assess the joint and cumulative impact of changes and reforms that happened in the crucial period between 2003 and 2005 . We can also try to get a deeper understanding of the changes taking place by modelling interaction effects to compare differences across industrial sectors and firm size.

More specifically, one possible hypothesis is that the turn from an investment to a production model - if indeed, it has happened - should be less pronounced in large firms, firms in the industrial sectors at the core of the German export economy and firms that train according to the investment model. This hypothesis suggests that firms that were committed to the system before remain committed through their investment in training. An alternative hypothesis would be that those firms that were pushed to invest in skill formation under the old institutional regime will now be more likely to make use of the less constraining environment compared with firms following the production model. If the latter hypothesis is correct, we would expect the productive contributions of apprentices to increase more strongly in large firms, firms in industrial sectors and firms following the investment model. 


\section{EMPIRICAL ANALYSIS}

\subsection{Data source}

The data sources for our analysis of the change in the training behaviour of German firms are two cross-sections of the Cost-Benefit Survey (CBS) of the BIBB. CBS by the BIBB have a long history and were first conducted in 1980 (Noll et al., 1983), followed by waves for 1990 (Bardeleben et al., 1991; 1995) and 2000 (Beicht et al., 2004). The latest BIBB-CBS was conducted in 2007 (Schönfeld et al., 2010). All surveys are based on the cost model developed by the Expert Commission on Costs and Financing of Vocational Education and Training (1974). Although the original cost-benefit model has been slightly adapted over time, the basic concepts of measuring training costs and benefits have remained practically unchanged.

The data were obtained through computer-assisted personal interviews in training firms. The person responsible for training in the firm (which, in the case, of small firms was often the owner of the firm) answered questions on the costs and benefits of training. While the assessment of some cost factors (such as apprentices' wages or costs for material) is relatively straightforward, the measurement of costs for trainers is somewhat more complex. The idea of the expert commission was to survey the time trainers (who could be full-time trainers, unskilled workers, skilled workers and/or management) spend with their apprentices $\left(h^{t}\right)$ and to value this time with the trainers' wage $\left(w^{t}\right)$. Since in many firms a good share of the training of apprentices is done on the job, a measure of productivity $\left(p^{t}\right)$ was used to correct for times that trainers spend with apprentices when at the same time they were performing at least part of their usual work. ${ }^{3}$ Hence the costs for trainers $\left(c^{t}\right)$ can be calculated as

$$
c^{t}=\left(1-p^{t}\right) h^{t} w^{t}
$$

A similar approach was chosen to calculate the productive contribution of the apprentices based on the type of work the apprentices performed. On the one hand, the time apprentices spend performing tasks that would otherwise be carried out by unskilled workers $\left(h^{u}\right)$ was valued with the wage of unskilled workers in the firm $\left(w^{u}\right)$. On the other hand, apprentices also often spend time on work usually done by skilled workers $\left(h^{s}\right)$. This amount of time is therefore multiplied by the wage of skilled workers $\left(w^{s}\right)$ and a relative productivity measure $\left(p^{s}\right)$, since apprentices are not yet as effective as skilled workers with a vocational degree. The firm's benefit in terms of the productive contribution of their apprentices $\left(B^{a}\right)$ is thus given by

$$
B^{a}=h^{u} w^{u}+p^{s} h^{s} w^{s}
$$

This leads to the following net costs for a firm in the training period $(N C)$

$$
N C=w^{a}+\left(1-p^{t}\right) h^{t} w^{t}+X-\left(h^{u} w^{u}+p^{s} h^{s} w^{s}\right)=C-B^{a},
$$

Where $X$ represents the remaining training costs such as expenses for teaching material and equipment.

\footnotetext{
${ }^{3}$ An example of this is the case of a skilled painter who trains an apprentice. The trainer could be instructing the apprentice while painting a wall. Since this time spend with the apprentice does not restrain the trainer's productivity performing his/her job, the productive measure $p^{t}$ has a value of 1 and the costs for this instruction time are zero. In the survey the productivity measure is used to calculate the costs for full- or part-time trainers.
} 
For the analysis in this article, we merged the two latest waves of the BIBB-CBS from 2000 and 2007, respectively. We have included only those firms in the sample that report having been involved in apprenticeship during the three preceding years; we excluded firms that are not, or not regularly, involved in training. The resulting sample is composed of 1,616 training firms for the year 2000 and 2,368 training firms for the year 2007 and is sufficiently large for an in-depth analysis of training costs and training behaviour. ${ }^{4}$

\subsection{Variable construction and estimation model}

In our empirical analysis, we focused on three different dependent variables as defined earlier: the productive contributions of apprentices $B^{a}$, the gross costs of training and the net costs of training. Here, it is important to note the dual nature of training costs as defined in the BIBB survey. On the one hand, costs reflect voluntary decisions by firms to invest in training. Firms in the German training regime can always reduce their training costs to zero by dropping out of training. On the other hand, costs are also influenced by external constraints such as collective wage bargaining agreements stipulating wage rates for apprentices and trainers. The measure of productive contributions is a more direct indicator of how much use firms can make of apprentices in regular work processes given the external constraints. Looking at costs and benefits jointly thus provides a relatively broad perspective on firms' individual training decisions.

We include several control variables: first, we use a common measure of training motivations to distinguish between firms that train according to the investment model and firms that train according to the production model. Firms are coded as following an investment model if they retain all apprentices in a given year as this clearly indicates that apprenticeship training is regarded as a gateway to internal labour markets. Conversely, firms are coded as following a pure production model when they retain no apprentices at all. All other firms are coded in an intermediary category ('mixed models'). Of course, this is a rather strict definition. Empirically, about 34 per cent of training firms in 2007 retained all apprentices who finished their apprenticeships successfully between 2005 and 2007, while about 40 per cent retained no one. In 2000 , the number of firms retaining all apprentices was slightly higher (44 per cent), while 33 per cent did not retain any apprentices (see Table A1). Relaxing the threshold definitions (to 80 and 20 per cent, respectively) does not change the results of the estimation either (results available from the authors). In general, the relative shares of firms following either the production or the investment model vary somewhat across firm size categories as well as economic sectors (see Table A2).

Furthermore, we control for firm size and economic sector (or more specifically, the particular group of vocations/occupations that firms' apprentices are trained in). We also include a dummy variable to capture differences between East and West Germany (West $=1$ ) and a dummy variable for establishments in the public sector. Finally, we include a variable that indicates whether firms are (voluntarily) bound to collective wage bargaining agreements when setting apprentices' wages.

Again, we are mostly interested in changes over time. To capture the overall trend, we included a dummy variable for the year 2007. More important, however, are the interactions. We include interaction terms of firm size, training model and occupa-

\footnotetext{
${ }^{4}$ For more details concerning the merging of the two waves, see Pfeifer et al. (2010).
} 
tional group (i.e. industrial sector). Each of these variables is interacted with the year dummy. We used this method to find out whether there are differences in development over time across these categories. Because the dependent variable is cardinal, we can employ simple and straightforward ordinary least squares analysis.

\subsection{Results}

In Table 1, we present bivariate results for benefits, gross costs and net costs for different firm characteristics for each year of observation. ${ }^{5}$ Benefits (measured as the productive contributions of apprentices) rose significantly by about 41 per cent overall, whereas gross costs increased only slightly, by about 10 per cent. As a consequence, net costs declined from 6,233 euros per apprentice in 2000 to 4,334 euros per apprentice in 2007 (a drop of 30 per cent). There are almost no differences in the development of benefits between small (up to 10 employees) and medium-sized (10-49 and 50-499 employees) firms. Benefits increased by roughly 40 per cent for both groups. In large firms, however, the increase is much stronger ( 83 per cent). This initial evidence supports the notion that large firms have partly turned from the investment to the production model.

Table 2 presents the results of our statistical analysis of apprentices' productive contributions. In Model I, we included dummies for year, firm size, training model, occupational group and region, plus a dummy for whether the firm is subject to collective wage bargaining as independent variables. In Model II, we added interaction terms with the year dummy.

Several things can be noted: first, as expected, the overall trend is a significant increase in the productive contribution of apprentices. The coefficient of the year dummy indicates a statistically significant average increase in the productive contributions that is equal to a value of 3,459 euros per apprentice (Model I). This is clearly a very significant increase in training benefits in such a short period of time.

Second, the training model (measured as defined earlier) does not have an effect on the benefits of training. This is somewhat surprising because we could have expected firms following an investment model to be willing to accept a lower productive contribution by apprentices compared with firms following the production model. The effect of the variable capturing training models could be dominated by the effects of other variables, such as firm size. However, the bivariate correlations between these variables are not very strong so there is no significant problem of multi-collinearity.

Third, firm size has a large effect on the productive contributions of apprentices. Interestingly, the productive contributions of apprentices are largest in medium-sized firms and smaller in very small and large firms (see Model I, Table 1). In order to understand this pattern, it is useful to remember that the productive contributions of apprentices also depend on apprentices' ability to replace skilled workers and the wages of these workers. Because the percentage of skilled workers and skilled (higher) wages is higher in medium-sized firms, the productive contributions of apprentices are proportionately larger. ${ }^{6}$ Furthermore, firms might be willing to accept lower productive contributions of apprentices for a period of time when they undergo additional training in on-the-job training courses. The largest contribution by apprentices can

\footnotetext{
${ }^{5}$ See Table A1 for descriptive statistics of these variables.

${ }^{6}$ In terms of the number of days that apprentices work on production-related tasks, small firms actually rank above medium-sized firms (results not shown here).
} 
Table 1: Average benefits, gross costs and net costs for different firm characteristics in euros

\begin{tabular}{|c|c|c|c|c|c|c|c|c|c|c|c|c|}
\hline & \multicolumn{4}{|c|}{ Benefits } & \multicolumn{4}{|c|}{ Gross costs } & \multicolumn{4}{|c|}{ Net costs } \\
\hline & \multicolumn{2}{|c|}{2000} & \multicolumn{2}{|c|}{2007} & \multicolumn{2}{|c|}{2000} & \multicolumn{2}{|c|}{2007} & \multicolumn{2}{|c|}{2000} & \multicolumn{2}{|c|}{2007} \\
\hline & Mean & $\begin{array}{l}\text { Standard } \\
\text { Deviation }\end{array}$ & Mean & $\begin{array}{l}\text { Standard } \\
\text { Deviation }\end{array}$ & Mean & $\begin{array}{l}\text { Standard } \\
\text { Deviation }\end{array}$ & Mean & $\begin{array}{l}\text { Standard } \\
\text { Deviation }\end{array}$ & Mean & $\begin{array}{l}\text { Standard } \\
\text { Deviation }\end{array}$ & Mean & $\begin{array}{l}\text { Standard } \\
\text { Deviation }\end{array}$ \\
\hline \multicolumn{13}{|l|}{ Firm size } \\
\hline 1-9 employees & $8,042.33$ & $4,063.22$ & $11,190.99$ & $4,882.03$ & $14,043.35$ & $5,478.15$ & $14,787.83$ & $6,892.02$ & $6,001.02$ & $6,189.13$ & $3,596.85$ & $8,302.85$ \\
\hline 10-49 employees & $8,174.53$ & $4,215.12$ & $11,566.02$ & $5,184.32$ & $14,534.30$ & $6,454.71$ & $16,516.85$ & $7,469.61$ & $6,359.76$ & $6,869.84$ & $4,950.84$ & $8,714.14$ \\
\hline 50-499 employees & $9,095.50$ & $4,846.22$ & $13,017.52$ & $6,417.93$ & $15,150.26$ & $5,498.12$ & $18,169.61$ & $8,037.62$ & $6,054.76$ & $7,214.81$ & $5,152.09$ & $10,234.75$ \\
\hline More than 499 employees & $6,936.87$ & $4,395.24$ & $12,704.75$ & $7,093.31$ & $19,367.11$ & $8,819.83$ & $21,484.40$ & $8,854.21$ & $12,430.24$ & $9,584.74$ & $8,779.64$ & $12,264.66$ \\
\hline \multicolumn{13}{|l|}{ Training model } \\
\hline Investment model & $8,292.26$ & $4,129.06$ & $11,670.05$ & $5,326.90$ & $14,937.14$ & $6,284.55$ & $16,537.65$ & $7,269.87$ & $6,644.87$ & $7,251.04$ & $4,867.61$ & $8,493.31$ \\
\hline Mixed model & $8,024.17$ & $4,585.90$ & $11,358.74$ & $5,557.12$ & $14,124.08$ & $5,864.31$ & $16,231.54$ & $7,863.77$ & $6,099.91$ & $6,683.45$ & $4,872.80$ & $9,464.81$ \\
\hline Production model & $8,247.91$ & $4,172.00$ & $11,628.78$ & $5,029.32$ & $14,023.34$ & $5,636.11$ & $15,173.61$ & $7,137.44$ & $5,775.43$ & $5,858.60$ & $3,544.82$ & $8,584.15$ \\
\hline \multicolumn{13}{|l|}{ Occupational group } \\
\hline Metalworking & $6,953.33$ & $3,962.38$ & $9,570.34$ & $4,348.15$ & $14,561.25$ & $5,985.91$ & $17,203.13$ & $8,389.77$ & $7,607.92$ & $7,350.69$ & $7,632.79$ & $9,528.95$ \\
\hline Electrical engineering & $6,482.42$ & $3,369.87$ & $10,496.24$ & $4,822.39$ & $14,514.03$ & $6,488.45$ & $17,717.23$ & $8,688.71$ & $8,031.61$ & $6,647.11$ & $7,221.00$ & $10,099.45$ \\
\hline Information technology & $8,651.89$ & $3,902.10$ & $11,382.79$ & $5,157.33$ & $15,928.58$ & $7,354.37$ & $19,217.98$ & $7,812.77$ & $7,276.69$ & $8,383.63$ & $7,835.19$ & $8,675.58$ \\
\hline Chemicals & $5,503.96$ & 4,207.29 & $10,212.67$ & $5,901.90$ & $19,479.78$ & $8,240.27$ & $19,456.19$ & $7,658.89$ & $1,3975.82$ & $8,431.75$ & $9,243.52$ & $10,700.45$ \\
\hline Accommodation and food & $9,185.19$ & $4,238.58$ & $11,934.30$ & $4,908.89$ & $13,265.97$ & $5,587.50$ & $13,622.47$ & $6,055.17$ & $4,080.78$ & $6,265.24$ & $1,688.17$ & $6,838.57$ \\
\hline Construction & $8,834.01$ & $4,329.98$ & $10,786.49$ & $5,624.61$ & $14,437.47$ & $5,541.81$ & $14,814.26$ & $5,130.43$ & $5,603.46$ & $6,722.49$ & $4,027.77$ & $6,404.29$ \\
\hline Print and media & $7,754.51$ & $3,063.19$ & $13,361.88$ & $5,821.78$ & $18,571.88$ & $6,515.59$ & $20,683.14$ & $9,080.41$ & $10,817.37$ & 7,673.72 & $7,321.26$ & $11,711.09$ \\
\hline Health & $8,898.12$ & $4,240.60$ & $12,019.47$ & $4,618.42$ & $14,165.01$ & $4,730.48$ & $13,966.20$ & $5,794.46$ & $5,266.90$ & $4,832.07$ & $1,946.73$ & $7,905.53$ \\
\hline Administrative: Sales and distribution & $7,958.56$ & $4,433.83$ & $12,031.89$ & $5,176.70$ & $13,377.23$ & $4,425.77$ & $15,666.78$ & $7,933.44$ & $5,418.67$ & $5,358.63$ & $3,634.88$ & $9,138.70$ \\
\hline Administrative: Headquarters & $9,301.80$ & $4,329.37$ & $12,626.66$ & $5,908.82$ & $16,342.90$ & $7,838.43$ & $16,467.57$ & $7,353.58$ & $7,041.09$ & $7,697.41$ & $3,840.91$ & $8,775.62$ \\
\hline Administrative: Banks/insurance & $8,286.21$ & $4,832.20$ & $11,747.75$ & $5,637.21$ & $17,959.05$ & $4,836.40$ & $20,143.97$ & $7,272.51$ & $9,672.84$ & $7,011.56$ & $8,396.22$ & $9,853.06$ \\
\hline Other occupations & $6,304.67$ & $3,231.60$ & $11,118.03$ & $5,297.32$ & $11,834.06$ & $5,513.10$ & $13,775.21$ & $6,188.91$ & $5,529.38$ & $6,150.18$ & $2,657.18$ & $7,746.90$ \\
\hline Total & $8,217.48$ & $4,248.11$ & $11,575.30$ & $5,267.78$ & $14,450.08$ & $5,993.15$ & $15,909.27$ & $7,393.65$ & $6,232.60$ & $6,693.86$ & $4,333.97$ & $8,802.97$ \\
\hline
\end{tabular}

Source: BIBB Cost-Benefit Surveys 2000 and 2007. 
Table 2: Regression analysis of productive contributions of apprentices, 2000 and 2007

\begin{tabular}{|c|c|c|c|c|}
\hline & \multicolumn{2}{|c|}{ Model I } & \multicolumn{2}{|c|}{ Model II } \\
\hline & Coefficient. & Standard Error & Coefficient & Standard Error \\
\hline Year & $3,459.22 * * *$ & 162.43 & $2,882.63^{* * *}$ & 550.83 \\
\hline \multicolumn{5}{|c|}{ Training model: Reference group: investment model } \\
\hline Dummy mixed model & -63.08 & 188.75 & -43.25 & 299.12 \\
\hline Dummy production model & 250.30 & 202.35 & 263.57 & 314.00 \\
\hline \multicolumn{5}{|l|}{ Firm size: ref.: 1-9 employees } \\
\hline 10-49 employees & $714.56^{* * *}$ & 210.55 & 372.42 & 329.50 \\
\hline 50-499 employees & $1,790.58 * * *$ & 242.52 & $1,025.70 * * *$ & 380.01 \\
\hline More than 499 employees & $1,136.14 * * *$ & 338.75 & -97.09 & 510.43 \\
\hline \multicolumn{5}{|c|}{ Occupational group: Reference group: administrative: headquarters } \\
\hline Metalworking & $-2,889.83^{* * *}$ & 292.10 & $-2,129.90 * * *$ & 422.56 \\
\hline Electrical engineering & $-2,654.27 * * *$ & 312.07 & $-2,332.97 * * *$ & 514.27 \\
\hline Information technology & -623.05 & 400.71 & -201.45 & 811.05 \\
\hline Chemicals & $-3,804.86^{* * *}$ & 670.05 & $-3,677.20^{* * *}$ & $1,093.22$ \\
\hline Accommodation and food & -145.17 & 286.62 & 183.08 & 452.77 \\
\hline Construction & $-1,131.88^{* * *}$ & 349.82 & -146.86 & 528.44 \\
\hline Print and media & $-1,053.91^{* *}$ & 444.32 & $-1,463.20^{* *}$ & 668.46 \\
\hline Health & $-848.71 * *$ & 392.89 & -663.82 & 558.44 \\
\hline Administrative: sales and distribution & -377.57 & 307.02 & $-938.48^{*}$ & 503.01 \\
\hline Administrative: banks/insurance & $-866.81 * *$ & 406.42 & -755.88 & 616.93 \\
\hline Other occupations & $-2,020.05^{* * *}$ & 407.93 & $-1,688.86^{* * *}$ & 617.90 \\
\hline Region $($ West $=1)$ & $2,778.10^{* * *}$ & 188.92 & $2,783.82 * * *$ & 189.28 \\
\hline Public service & $-1,238.23^{* * *}$ & 277.97 & $-1,199.16^{* * *}$ & 278.57 \\
\hline Collective wage bargaining & $-298.95^{*}$ & 178.29 & $-494.15^{*}$ & 288.06 \\
\hline \multicolumn{5}{|l|}{ Interaction terms with year: } \\
\hline Interaction 10-49 employees & & & 612.16 & 428.00 \\
\hline Interaction 50-499 employees & & & $1,290.55^{* * *}$ & 489.14 \\
\hline Interaction more than 499 employees & & & $2,167.52 * * *$ & 672.54 \\
\hline Interaction mixed models & & & -63.67 & 385.38 \\
\hline Interaction production model & & & 6.85 & 411.06 \\
\hline Interaction metalworking & & & $-1,372.38 * *$ & 561.30 \\
\hline Interaction electrical engineering & & & -591.33 & 631.55 \\
\hline Interaction information technology & & & -701.00 & 930.01 \\
\hline Interaction chemicals & & & -239.14 & 1367.57 \\
\hline Interaction accommodation and food & & & -548.43 & 570.06 \\
\hline Interaction construction & & & $-1,753.61 * *$ & 692.93 \\
\hline Interaction print and media & & & 720.25 & 878.81 \\
\hline Interaction health & & & -379.19 & 779.33 \\
\hline $\begin{array}{l}\text { Interaction administrative: sales and } \\
\text { distribution }\end{array}$ & & & 877.26 & 621.91 \\
\hline $\begin{array}{l}\text { Interaction administrative: } \\
\text { banks/insurance }\end{array}$ & & & -190.12 & 809.39 \\
\hline Interaction other occupations & & & -592.94 & 822.95 \\
\hline Interaction collective wage bargaining & & & 338.25 & 357.56 \\
\hline Constant & $6,453.05^{* * *}$ & 321.53 & $6,790.40^{* * *}$ & 455.32 \\
\hline Observations & & 984 & & 984 \\
\hline Adjusted R-squared & & 186 & & 190 \\
\hline
\end{tabular}

Source: BIBB Cost-Benefit Surveys 2000 and 2007.

* significant at the $10 \%$-level, ${ }^{* *}$ significant at the $5 \%$-level, *** significant at the $1 \%$-level. 
Table 3: Predicted values for productive contributions of apprentices (in euros)

\begin{tabular}{lccccc}
\hline & \multicolumn{2}{c}{2000} & & \multicolumn{2}{c}{2007} \\
\cline { 2 - 3 } \cline { 6 - 7 } & Mean & $\begin{array}{c}\text { Standard } \\
\text { Deviation }\end{array}$ & & Mean & $\begin{array}{c}\text { Standard } \\
\text { Deviation }\end{array}$ \\
\hline Overall average & $8,179.28$ & $1,417.53$ & & $11,474.5$ & $1,675.27$ \\
1-9 employees & $8,101.18$ & $1,343.21$ & & $10,985.45$ & $1,435.64$ \\
10-49 employees & $8,195.83$ & $1,477.84$ & & $11,629.66$ & $1,633.07$ \\
50-499 employees & $8,579.29$ & $1,525.43$ & & $12,888.11$ & $1,754.79$ \\
More than 500 employees & $7,676.45$ & $1,556.9$ & & $12,369.78$ & $1,633.39$ \\
\hline
\end{tabular}

Source: BIBB Cost-Benefit Surveys 2000 and 2007.

therefore be observed in the medium-sized firms, where apprentices regularly replace skilled workers.

With regard to occupational groups, we find that the reference group 'Administrative: Headquarters' exhibits the highest level of productive contributions as the coefficients of all occupational groups are negative in Model I. The productive contributions in skill-intensive occupations (mostly metalworking, electrical engineering and chemicals but not in information technology) are particularly low as expected. The productive contributions of apprentices are significantly higher in West Germany, largely because the wages for skilled workers are higher there. The productive contributions of apprentices are significantly lower in public sector establishments. The existence of a binding collective wage bargaining agreement induces slightly lower productive contributions by apprentices, but the effect is small in magnitude and on the border of statistical significance.

The most interesting finding for the purposes of this article is that there are significant interaction effects between independent variables and the time dummy. More specifically, there are significant differences across firm size categories. Table 3 provides predicted values based on Model II of Table 2. This table shows that the productive contributions in large firms increased by about 1,800 euros more per apprentice than in very small firms (the base category). This effect is observed in addition to the overall trend. Medium-sized firms (50-499 employees) also profited from an above average increase in the productive contributions of apprentices (1,400 euros).

In Model II, we also test whether there are other factors besides firm size that matter. As seen before, the training model does not have any effect on the productive contributions of apprentices. The interaction with occupational groups produces some significant results but not many. Only metalworking and construction occupations run counter to the trend because the productive contributions of apprentices in these firms increased less in comparison with the reference group. This shows that firms in these sectors are more reluctant to move towards the production model as they are tied to skill-intensive production strategies. Finally, the interaction with collective wage bargaining does not produce statistically significant results. The wave of 2007 also included a variable capturing the presence of a works council, which may be more important than collective wage bargaining as such. Unfortunately, the 2000 wave did not include this variable so we can not test for this in our sample. 
In Table 3, we present predicted values of the productive contributions of apprentices across different firm size categories. This makes the results of Table 2 easier to interpret. Again, we can see that the increase in productive contributions was largest for the large firms.

Table 4 contains the results of an analysis of gross and net costs. The estimates show that gross costs increased between 2000 and 2007, whereas net costs actually fell as a result of the increase in benefits provided by the increased productive contributions of apprentices (see also Schönfeld et al., 2010). We also find that there is a statistically significant and positive association between training costs (both gross and net costs) and firm size. This is a well-established finding in the literature and reflects large firms' pursuit of training strategies based on the investment model (Mohrenweiser and Backes-Gellner, 2010; Neubäumer and Bellmann, 1999). For the purposes of the present article, the striking finding is that in contrast to the development in benefits, there is no significant interaction effect between firm size and time trend in the case of gross costs. This means that large firms did not reduce their gross training expenditures in 2007 (although the coefficient estimate does have a negative sign). In the case of net costs, we find a large and significant negative interaction effect between the time trend and the largest firm category.

In sum, these findings indicate that large firms in 2007 experienced greater increases in benefits than did small firms, resulting in significantly lower net training costs despite the fact that gross costs remained unaffected. To put it simply, large firms have maintained the same gross levels of training investment but have still been able to reduce their net costs because the productive contributions of apprentices have risen significantly, a development that is most likely related to the overall transformation of the German industrial relations framework.

\section{DISCUSSION AND CONCLUSIONS}

This article has discussed how recent changes in the German political economy have affected the training decisions of firms at the micro level. The further erosion of collective wage bargaining, in conjunction with reform efforts to flexibilise the training system, would lead us to expect firms to move from the investment model to the production model of training. But such a move en masse has not occurred as two of the authors have shown in related work (Pfeifer et al. (2010)). A significant percentage of firms in Germany continue to train according to the logic of the investment model, using apprenticeship training as a gateway to internal labour markets. The present article adds to this finding by showing that the productive contributions of apprentices increased significantly between 2000 and 2007. This indicates that the training of apprentices has now been integrated into regular work processes much more intensely. The new perspective that this article adds to the literature is to argue and show empirically that increases in the productive contributions of apprentices are strongly correlated with firm size. Large firms that are traditionally more likely to train according to the investment model have seen the largest increases in productive contributions, whereas small firms have not benefited above and beyond the overall positive trend.

Taken as a whole, the findings of this article might therefore help to explain the apparent resilience of the German training system against the effects of the economic and financial crisis, as well as to assess the future viability of the German training system. One could say that the price for German employers to continue their 
Table 4: Regression analysis of gross and net costs of apprenticeship training, 2000 and 2007

\begin{tabular}{|c|c|c|c|c|}
\hline & \multicolumn{2}{|c|}{ Gross costs } & \multicolumn{2}{|c|}{ Net costs } \\
\hline & Coefficient & SE & Coefficient & SE \\
\hline Year & $1,412.84^{*}$ & 748.66 & $-1,469.79$ & 924.76 \\
\hline \multicolumn{5}{|l|}{ Training model: Reference group: investment model } \\
\hline Dummy mixed model & $-871.50^{* *}$ & 406.55 & $-828.25^{*}$ & 502.18 \\
\hline Dummy production model & -441.35 & 426.77 & -704.93 & 527.16 \\
\hline \multicolumn{5}{|l|}{ Firm size: Ref.: $1-9$ employees } \\
\hline 10-49 employees & 515.75 & 447.85 & 143.34 & 553.19 \\
\hline 50-499 employees & $1,501.86^{* * *}$ & 516.49 & 476.15 & 637.99 \\
\hline More than 499 employees & $5,535.41 * * *$ & 693.75 & $5,632.50 * * *$ & 856.94 \\
\hline \multicolumn{5}{|c|}{ Occupational group: Reference group: administrative: headquarters } \\
\hline Metalworking & $1,809.89^{* * *}$ & 574.32 & $3,939.79 * * *$ & 709.42 \\
\hline Electrical engineering & $2,042.04 * * *$ & 698.97 & $4,375.02 * * *$ & 863.38 \\
\hline Information technology & $2,348.28 * *$ & $1,102.34$ & $2,549.73^{*}$ & $1,361.64$ \\
\hline Chemicals & $4,402.28 * * *$ & $1,485.85$ & $8,079.48 * * *$ & $1,835.36$ \\
\hline Accommodation and food & -890.62 & 615.38 & $-1,073.70$ & 760.14 \\
\hline Construction & 149.73 & 718.23 & 296.59 & 887.17 \\
\hline Print and media & $2,858.56^{* * *}$ & 908.54 & $4,321.76^{* * *}$ & $1,122.25$ \\
\hline Health & -443.91 & 759.00 & 219.90 & 937.53 \\
\hline Administrative: sales and distribution & $-1279.10^{*}$ & 683.67 & -340.62 & 844.49 \\
\hline Administrative: banks/insurance & $2,104.90^{* *}$ & 838.50 & $2,860.78^{* * *}$ & $1,035.73$ \\
\hline Other occupations & -997.43 & 839.82 & 691.43 & $1,037.37$ \\
\hline Region $($ West $=1)$ & $3,966.53^{* * *}$ & 257.26 & $1,182.71^{* * *}$ & 317.77 \\
\hline Public service & -368.88 & 378.61 & $830.28 *$ & 467.67 \\
\hline Collective wage bargaining & 105.98 & 391.52 & 600.13 & 483.62 \\
\hline \multicolumn{5}{|l|}{ Interaction terms with year: } \\
\hline Interaction 10-49 employees & -495.22 & 523.79 & -431.55 & 647.00 \\
\hline Interaction 50-499 employees & -774.74 & 558.69 & -781.59 & 690.10 \\
\hline Interaction more than 499 employees & 625.69 & 581.72 & 13.53 & 718.56 \\
\hline Interaction mixed models & 645.77 & 664.82 & -644.78 & 821.20 \\
\hline oduction model & $-1,139.56$ & 914.09 & $-3,307.07 * * *$ & $1,129.11$ \\
\hline Interaction metalworking & -766.03 & 762.89 & 606.35 & 942.34 \\
\hline Interaction electrical engineering & 234.32 & 858.38 & 825.65 & $1,060.29$ \\
\hline Interaction information technology & -647.34 & $1,264.02$ & 53.67 & $1,561.35$ \\
\hline Interaction chemicals & -223.03 & $1,858.73$ & 16.10 & $2,295.95$ \\
\hline Interaction accommodation and food & $-1,861.77 * *$ & 774.79 & $-1,313.34$ & 957.04 \\
\hline Interaction construction & $-1,172.23$ & 941.80 & 581.38 & $1,163.33$ \\
\hline Interaction print and media & 434.15 & $1,194.43$ & -286.10 & $1,475.39$ \\
\hline Interaction health & -569.48 & $1,059.23$ & -190.29 & $1,308.39$ \\
\hline Interaction administrative: sales and distribution & 593.72 & 845.27 & -283.54 & $1,044.10$ \\
\hline Interaction administrative: banks/insurance & 500.34 & $1,100.08$ & 690.46 & $1,358.85$ \\
\hline Interaction other occupations & $-1,188.00$ & $1,118.52$ & -595.06 & $1,381.62$ \\
\hline Interaction collective wage bargaining & 769.83 & 485.98 & 431.58 & 600.30 \\
\hline Constant & $11,150.96^{* * *}$ & 618.85 & $4,360.56^{* * *}$ & 764.41 \\
\hline Observations & \multicolumn{2}{|l|}{3,984} & \multicolumn{2}{|l|}{3,984} \\
\hline Adjusted R-squared & \multicolumn{2}{|l|}{0.188} & \multicolumn{2}{|l|}{0.138} \\
\hline
\end{tabular}

Source: BIBB Cost-Benefit Surveys 2000 and 2007.

* significant at the $10 \%$-level, ** significant at the 5\%-level, *** significant at the $1 \%$-level. 
commitment to apprenticeship training is to reconfigure the institutional setup of the training system so that firms can extract more benefit (in terms of productive contributions) from their apprentices. While the overall numbers of apprentices have remained constant or even increased slightly in recent years, recent developments may actually increase labour market segmentation by enhancing the cleavage between apprentices trained as skilled workers for internal labour markets, on the one hand, and those employed as inexpensive substitutes for semi-skilled labour, on the other.

Reflecting on avenues for future research, we see a need to develop better indicators to measure individual firms' training models. For example, it would be important to be able to differentiate between cost increases that are due to changes in the exogenous environment (e.g. changes in collective wage bargaining agreements) and cost increases that simply reflect changes in employers' willingness to invest above the minimum requirement (investments in the narrow sense). Actors at the firm level face fewer constraints when deciding on the latter type of increases, whereas they must often accept the former type as a given in the short term. We would also encourage cross-national comparison between Germany and other collective skill formation systems (Busemeyer and Trampusch, 2012). The institutional cooperation between the $\mathrm{BIBB}$ and the Centre for Research in Economics of Education at the University of Bern has ensured that the data source used in this article is compatible with data on Swiss firms and can be used for cross-national comparisons between the two countries (Dionisius et al. 2009). Clearly, more research along these lines would be very welcome.

\section{References}

Acemoglu, D. and J.-S. Pischke (1998), 'Why Do Firms Train? Theory and Evidence', Quarterly Journal of Economics, 113, 1, 79-119.

Acemoglu, D. and J.-S. Pischke (1999), 'Beyond Becker: Training in Imperfect Labour Markets', Economic Journal, 109, 453, F112-F142.

Acemoglu, D. and J.-S. Pischke (2000), 'Certification of Training and Training Outcomes', European Economic Review, 44, 4-6, 917-927.

Alewell, D. (1997), Die Finanzierung betrieblicher Weiterbildungsinvestitionen: Ökonomische und juristische Aspekte (Wiesbaden, Gabler).

Alewell, D. (1998), 'Warum finanzieren Arbeitgeber transferierbare Weiterbildung?', Zeitschrift für betriebswirtschaftliche Forschung, 50, 4, 315-335.

Bardeleben, R. V., U. Beicht and K. Fehér (1995), Betriebliche Kosten und Nutzen der Ausbildung. Repräsentative Ergebnisse aus Industrie, Handel und Handwerk (Bielefeld, Bertelsmann).

Bardeleben, R. V., U. Beicht and R. Stockmann (1991), Kosten und Nutzen der betrieblichen Berufsbildung. Forschungsstand -Konzeption-Erhebungsinstrumentarium (Bonn, Bundesinstitut für Berufsbildung).

Becker, G. S. (1993), Human Capital: A Theoretical and Empirical Analysis with Special Reference to Education, 3rd edn (Chicago, IL, University of Chicago Press).

Beicht, U., G. Walden and H. Herget (2004), Kosten und Nutzen der betrieblichen Berufsausbildung in Deutschland (Bielefeld, Bertelsmann).

Bosch, G. (2010), 'Zur Zukunft der dualen Ausbildung in Deutschland', in G. Bosch, S. Krone and D. Langer (eds), Das Berufsbildungssystem in Deutschland: Aktuelle Entwicklungen und Standpunkte (Wiesbaden, VS Verlag für Sozialwissenschaften) pp. 37-61.

Bosch, G. and J. Charest (2008), 'Vocational Training and the Labour Market in Liberal and Coordinated Market Economies', Industrial Relations Journal, 39, 5, 428-447.

Busemeyer, M. R. (2009a), 'Die Sozialpartner und der Wandel in der Politik der beruflichen Bildung Seit 1970', Industrielle Beziehungen, 16, 3, 273-294. 
Busemeyer, M. R. (2009b), 'Europäisierung der deutschen Berufsbildungspolitik', Aus Politik und Zeitgeschichte, 2009, 45, 25-31.

Busemeyer, M. R. (2009c), Wandel trotz Reformstau: Die Politik der Beruflichen Bildung seit 1970 (Frankfurt/Main, Campus).

Busemeyer, M. R. (2012), 'Business as a Pivotal Actor in the Politics of Training Reform: Insights from the Case of Germany', British Journal of Industrial Relations, Early View, http://onlinelibrary.wiley.com/doi/10.1111/j.1467-8543.2012.00900.x/abstract.

Busemeyer, M. R. and C. Trampusch (eds) (2012), The Political Economy of Collective Skill Formation (Oxford, Oxford University Press).

Casey, C., A. Fiedler and J. Erakovic (2012), 'Liberalising the German Model: Institutional Change, Organisational Restructuring and Workplace Effects', Industrial Relations Journal, 43, 1, 53-69.

Dionisius, R., S. Mühlemann, H. Pfeifer, G. Walden, F. Wenzelmann and S. C. Wolter (2009), 'Cost and Benefit of Apprenticeship Training - A Comparison of Germany and Switzerland', Applied Economics Quarterly, 55, 1, 7-37.

Dustmann, C., J. Ludsteck and U. Schönberg (2009), 'Revisiting the German Wage Structure', Quarterly Journal of Economics, 124, 2, 843-881.

Expert Commission on Costs and Financing of Vocational Education and Training (1974), Sachverständigenkommission Kosten und Finanzierung der beruflichen Bildung. (Abschlussbericht, Bielefeld).

Feuer, M. J., H. A. Glick and A. Desai (1991), 'Firm Financed Education and Specific Human Capital', in D. Stern and J. M. M. Ritzen (eds), Market Failure in Training? New Economic Analysis and Evidence on Training of Adult Employees (Berlin, Springer) pp. 41-60.

Finegold, D. and D. Soskice (1988), 'The Failure of Training in Britain: Analysis and Prescription', Oxford Review of Economic Policy, 4, 3, 21-53.

Franz, W. and D. Soskice (1995), 'The German Apprenticeship System', in F. Buttler, W. Franz, R. Schettkat and D. Soskice (eds), Institutional Frameworks and Labor Market Performance: Comparative Views on the U.S. and German Economies (London, Routledge) pp. 208-234.

Gernandt, J. and F. Pfeiffer (2006), 'Rising Wage Inequality in Germany', ZEW Discussion Paper 06-019, SOEP paper No. 14. Center for European Economic Research, Mannheim.

Gumbrell-McCormick, R. and R. Hyman (2006), 'Embedded Collectivism? Workplace Representation in France and Germany', Industrial Relations Journal, 37, 5, 473-491.

Hall, P. A. and D. Soskice (2001), 'An Introduction to Varieties of Capitalism', in P. A. Hall and D. Soskice (eds), Varieties of Capitalism: The Institutional Foundations of Comparative Advantage (Oxford, Oxford University Press) pp. 1-68.

Harhoff, D. and T. J. Kane (1997), 'Is the German Apprenticeship System a Panacea for the U.S. Labor Market?', Journal of Population Economics, 10, 2, 171-196.

Hashimoto, M. (1981), 'Firm-specific Human Capital as a Shared Investment', American Economic Review, 71, 3, 475-482.

Hassel, A. (1999), 'The Erosion of the German System of Industrial Relations', British Journal of Industrial Relations, 37, 3, 483-505.

Hassel, A. (2007), 'What Does Business Want? Labour Market Reforms in CMEs and Its Problems', in B. Hancké, M. Rhodes and M. Thatcher (eds), Beyond Varieties of Capitalism: Conflict, Contradictions, and Complementarities in the European Economy (Oxford, Oxford University Press) pp. 253-277.

Hassel, A. and B. Rehder (2001), 'Institutional Change in the German Wage Bargaining System - The Role of Big Companies', MPIfG Working Paper, 01/9. Max Planck Institute for the Study of Societies, Cologne, Germany.

Hoffmann, J. and R. Schmidt (2009), 'The Train Drivers' Strike in Germany 2007-2008: Warnings for the Future of the German Trade Union Movement?', Industrial Relations Journal, 40, 6, 524-533. 
Höpner, M. (2007), 'Coordination and Organization: The Two Dimensions of Nonliberal Capitalism', MPIfG Discussion Paper, 07, 12. Max Planck Institute for the Study of Societies, Cologne, Germany.

Katz, E. and A. Ziderman (1990), 'Investment in General Training: The Role of Information and Labour Mobility', Economic Journal, 100, 403, 1147-1158.

Kempf, T. (1985), Theorie und Empirie Betrieblicher Ausbildungsplatzangebote in der Dualen Berufsausbildung (Frankfurt/Main, Lang).

Kohn, K. (2006), 'Rising Wage Dispersion, After All! The German Wage Structure at the Turn of the Century', IZA Discussion Paper 2098. Institut zur Zukunft der Arbeit, Bonn.

Lane, C. (1990), 'Vocational Training and New Production Concepts in Germany: Some Lessons for Britain', Industrial Relations Journal, 21, 4, 248-259.

Lindley, R. M. (1975), 'The Demand for Apprentice Recruits by the Engineering Industry: 1951-1971', Scottish Journal of Political Economy, 22, 1, 1-24.

Lutz, B. and W. Sengenberger (1974), Arbeitsmarktstrukturen und öffentliche Arbeitsmarktpolitik: Eine Kritische Analyse von Zielen und Instrumenten (Göttingen, Schwartz).

Marsden, D. and P. Ryan (1990), 'Institutional Aspects of Youth Employment and Training Policy in Britain', British Journal of Industrial Relations, 28, 3, 351-369.

Menz, G. (2005), 'Old Bottles-New Wine: The New Dynamics of Industrial Relations', German Politics, 14, 2, 196-207.

Merrilees, W. (1983), 'Alternative Models of Apprentice Recruitment: With Special Reference to the British Engineering Industry', Applied Economics, 15, 1, 1-21.

Mohrenweiser, J. and U. Backes-Gellner (2010), 'Apprenticeship Training-What for: Investment or Substitution?', International Journal of Manpower, 31, 5, 545-562.

Neubäumer, R. (1999), Der Ausbildungsstellenmarkt der Bundesrepublik Deutschland: Eine Theoretische und Empirische Analyse (Berlin, Duncker \& Humblot).

Neubäumer, R. and L. Bellmann (1999), 'Ausbildungsintensität und Ausbildungsbeteiligung von Betrieben: Theoretische Erklärungen und empirische Ergebnisse auf der Basis des IABBetriebspanels 1997', in D. Beer, B. Frick, R. Neubäumer and W. Sesselmeier (eds), Die Wirtschaftlichen Folgen von Aus- und Weiterbildung (München and Mering, Rainer Hampp) pp. 1-43.

Noll, I., U. Beicht, G. Boll, W. Malcher and S. Wiederhold-Fritz (1983), Nettokosten der betrieblichen Berufsausbildung (Berlin, Beuth).

Pfeifer, H., F. Wenzelmann and G. Schönfeld (2010), 'Ausbildungskosten und das Übernahmeverhalten von Betrieben: Ein Vergleich der BIBB-Kosten- und Nutzenerhebungen der Jahre 2000 und 2007', Sozialer Fortschritt, 59, 6, 174-182.

Schmierl, K. (2001), 'Hybridisierung der industriellen Beziehungen in der BundesrepublikÜbergangsphänomen oder neuer Regulationsmodus?', Soziale Welt, 52, 4, 427-448.

Schönfeld, G., F. Wenzelmann, R. Dionisius, H. Pfeifer and G. Walden (2010), Kosten und Nutzen der Dualen Ausbildung aus Sicht der Betriebe. Ergebnisse der Vierten BIBB-KostenNutzen-Erhebung (Bielefeld, Bundesinstitut für Berufsbildung).

Seifert, H. and H. Massa-Wirth (2005), 'Pacts for Employment and Competitiveness in Germany', Industrial Relations Journal, 36, 3, 217-240.

Sengenberger, W. (ed.) (1978), Der Gespaltene Arbeitsmarkt: Probleme der Arbeitsmarktsegmentation (Frankfurt/Main, Campus).

Sengenberger, W. (1987), Struktur und Funktionsweise von Arbeitsmärkten: Die Bundesrepublik Deutschland im Internationalen Vergleich (Frankfurt/Main, Campus).

Silvia, S. J. and W. Schroeder (2007), 'Why Are German Employers Associations Declining? Arguments and Evidence', Comparative Political Studies, 40, 12, 1433-1459.

Stevens, M. (1994), 'Labour Contracts and Efficiency in On-the-job-training', Economic Journal, 104, 423, 408-419.

Streeck, W. (1989), 'Skills and the Limits of Neo-liberalism: The Enterprise of the Future as a Place of Learning', Work, Employment \& Society, 3, 1, 89-104. 
Streeck, W. (1994), 'Training and the New Industrial Relations: A Strategic Role for Unions?', in M. Regini (ed.), The Future of Labour Movements (London, Newbury Park, CA and New Delhi, Sage) pp. 250-269.

Streeck, W. (2004), 'Educating Capitalists: A Rejoinder to Wright and Tsakalotos', Socioeconomic Review, 2, 3, 425-438.

Streeck, W. (2009), Re-forming Capitalism: Institutional Change in the German Political Economy (Oxford, Oxford University Press).

Thelen, K. (2004), How Institutions Evolve: The Political Economy of Skills in Germany, Britain, the United States and Japan (Cambridge, Cambridge University Press).

Thelen, K. (2007), 'Contemporary Challenges to the German Vocational Training System', Regulation \& Governance, 1, 3, 247-260.

Thelen, K. and M. R. Busemeyer (2008), 'From Collectivism towards Segmentalism: Institutional Change in German Vocational Training', MPIfG Discussion Paper, 08, 13. Max Planck Institute for the Study of Societies, Cologne, Germany.

Thelen, K. and M. R. Busemeyer (2012), 'Institutional Change in German Vocational Training: From Collectivism toward Segmentalism', in M. R. Busemeyer and C. Trampusch (eds), The Comparative Political Economy of Collective Skill Formation Systems (Oxford, Oxford University Press) pp. 68-100.

Toft, C. (2004), International Labour Market and Social Policy Analysis: Essays on Segmentation, Cross-national Variation and European Union Regulation (Kassel, Kassel University Press).

Trampusch, C. (2009a), Der erschöpfte Sozialstaat: Transformation eines Politikfeldes (Frankfurt/Main, Campus).

Trampusch, C. (2009b), 'Europeanization and Institutional Change in Vocational Education and Training in Germany and Austria', Governance, 22, 3, 371-397.

Trampusch, C. (2010), 'Employers, the State and the Politics of Institutional Change: Vocational Education and Training in Austria, Germany and Switzerland', European Journal of Political Research, 49, 4, 545-573.

Wolter, S. C. (2008), 'Ausbildungskosten und -nutzen und die betriebliche Nachfrage nach Lehrlingen', Perspektiven der Wirtschaftspolitik, 9, s1, 90-108.

\section{APPENDIX}

Table A1: Descriptive statistics

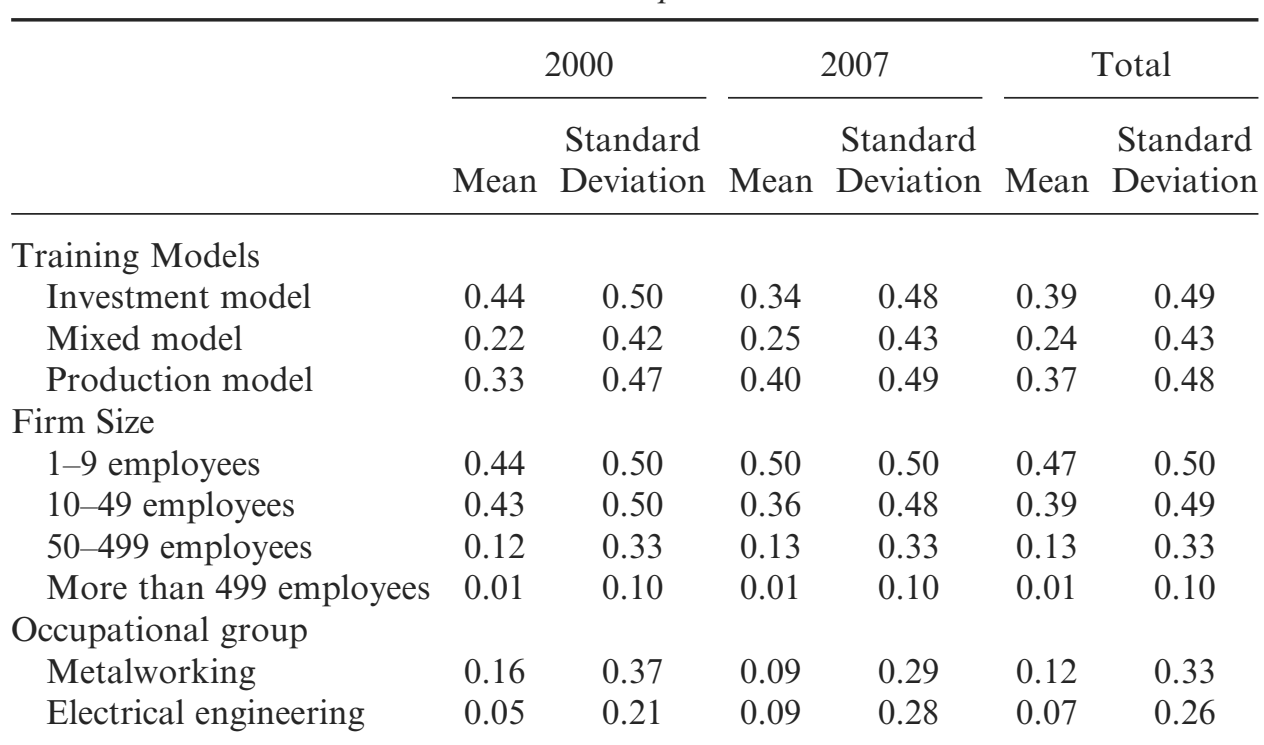


Table A1: Continued

\begin{tabular}{|c|c|c|c|c|c|c|}
\hline & \multicolumn{2}{|c|}{2000} & \multicolumn{2}{|c|}{2007} & \multicolumn{2}{|c|}{ Total } \\
\hline & Mean & $\begin{array}{l}\text { Standard } \\
\text { Deviation }\end{array}$ & Mean & $\begin{array}{l}\text { Standard } \\
\text { Deviation }\end{array}$ & Mean & $\begin{array}{l}\text { Standard } \\
\text { Deviation }\end{array}$ \\
\hline Information technology & 0.02 & 0.13 & 0.06 & 0.23 & 0.04 & 0.20 \\
\hline Chemicals & 0.00 & 0.04 & 0.01 & 0.07 & 0.00 & 0.06 \\
\hline $\begin{array}{l}\text { Accommodation and } \\
\text { food }\end{array}$ & 0.13 & 0.34 & 0.14 & 0.35 & 0.14 & 0.35 \\
\hline Construction & 0.11 & 0.31 & 0.10 & 0.31 & 0.10 & 0.31 \\
\hline Print and media & 0.03 & 0.17 & 0.02 & 0.14 & 0.03 & 0.16 \\
\hline Health & 0.14 & 0.35 & 0.12 & 0.33 & 0.13 & 0.34 \\
\hline $\begin{array}{l}\text { Administrative: Sales and } \\
\text { distribution }\end{array}$ & 0.15 & 0.36 & 0.14 & 0.35 & 0.15 & 0.35 \\
\hline $\begin{array}{l}\text { Administrative: } \\
\text { Headquarters }\end{array}$ & 0.14 & 0.34 & 0.18 & 0.38 & 0.16 & 0.37 \\
\hline $\begin{array}{l}\text { Administrative: } \\
\text { Banks/insurance }\end{array}$ & 0.02 & 0.13 & 0.02 & 0.14 & 0.02 & 0.14 \\
\hline Other occupations & 0.05 & 0.22 & 0.03 & 0.17 & 0.04 & 0.19 \\
\hline Region West & 0.81 & 0.39 & 0.84 & 0.37 & 0.83 & 0.38 \\
\hline Public service & 0.05 & 0.22 & 0.04 & 0.19 & 0.04 & 0.21 \\
\hline Collective wage bargaining & 0.67 & 0.47 & 0.56 & 0.50 & 0.61 & 0.49 \\
\hline
\end{tabular}

Source: BIBB Cost-Benefit Surveys 2000 and 2007.

Table A2: Shares or firms training according to the investment and production model in relation to firm size and economic sector

\begin{tabular}{|c|c|c|c|c|c|c|c|}
\hline & & \multicolumn{2}{|c|}{2000} & \multicolumn{2}{|c|}{2007} & \multicolumn{2}{|c|}{ Total } \\
\hline & & Mean & $\begin{array}{l}\text { Standard } \\
\text { Deviation }\end{array}$ & Mean & $\begin{array}{l}\text { Standard } \\
\text { Deviation }\end{array}$ & Mean & $\begin{array}{l}\text { Standard } \\
\text { Deviation }\end{array}$ \\
\hline \multicolumn{8}{|l|}{ Firm Size } \\
\hline \multirow[t]{3}{*}{$1-9$} & Investment model & 0.40 & 0.49 & 0.27 & 0.44 & 0.32 & 0.47 \\
\hline & Mixed model & 0.18 & 0.38 & 0.15 & 0.36 & 0.16 & 0.37 \\
\hline & Production model & 0.43 & 0.50 & 0.58 & 0.49 & 0.51 & 0.50 \\
\hline \multirow[t]{3}{*}{$10-49$} & Investment model & 0.49 & 0.50 & 0.39 & 0.49 & 0.43 & 0.50 \\
\hline & Mixed model & 0.29 & 0.45 & 0.35 & 0.48 & 0.33 & 0.47 \\
\hline & Production model & 0.23 & 0.42 & 0.25 & 0.44 & 0.24 & 0.43 \\
\hline \multirow[t]{3}{*}{$50-499$} & Investment model & 0.55 & 0.50 & 0.50 & 0.50 & 0.52 & 0.50 \\
\hline & Mixed model & 0.27 & 0.45 & 0.35 & 0.48 & 0.32 & 0.47 \\
\hline & Production model & 0.18 & 0.39 & 0.15 & 0.36 & 0.16 & 0.37 \\
\hline \multirow[t]{3}{*}{$500-25,000$} & Investment model & 0.54 & 0.50 & 0.45 & 0.50 & 0.49 & 0.50 \\
\hline & Mixed model & 0.29 & 0.46 & 0.43 & 0.50 & 0.38 & 0.49 \\
\hline & Production model & 0.17 & 0.37 & 0.11 & 0.32 & 0.13 & 0.34 \\
\hline \multicolumn{8}{|c|}{ Occupational group } \\
\hline \multirow[t]{3}{*}{ Metalworking } & Investment model & 0.43 & 0.50 & 0.32 & 0.47 & 0.38 & 0.49 \\
\hline & Mixed model & 0.30 & 0.46 & 0.32 & 0.47 & 0.31 & 0.46 \\
\hline & Production model & 0.27 & 0.44 & 0.36 & 0.48 & 0.31 & 0.46 \\
\hline
\end{tabular}


Table A2: Continued

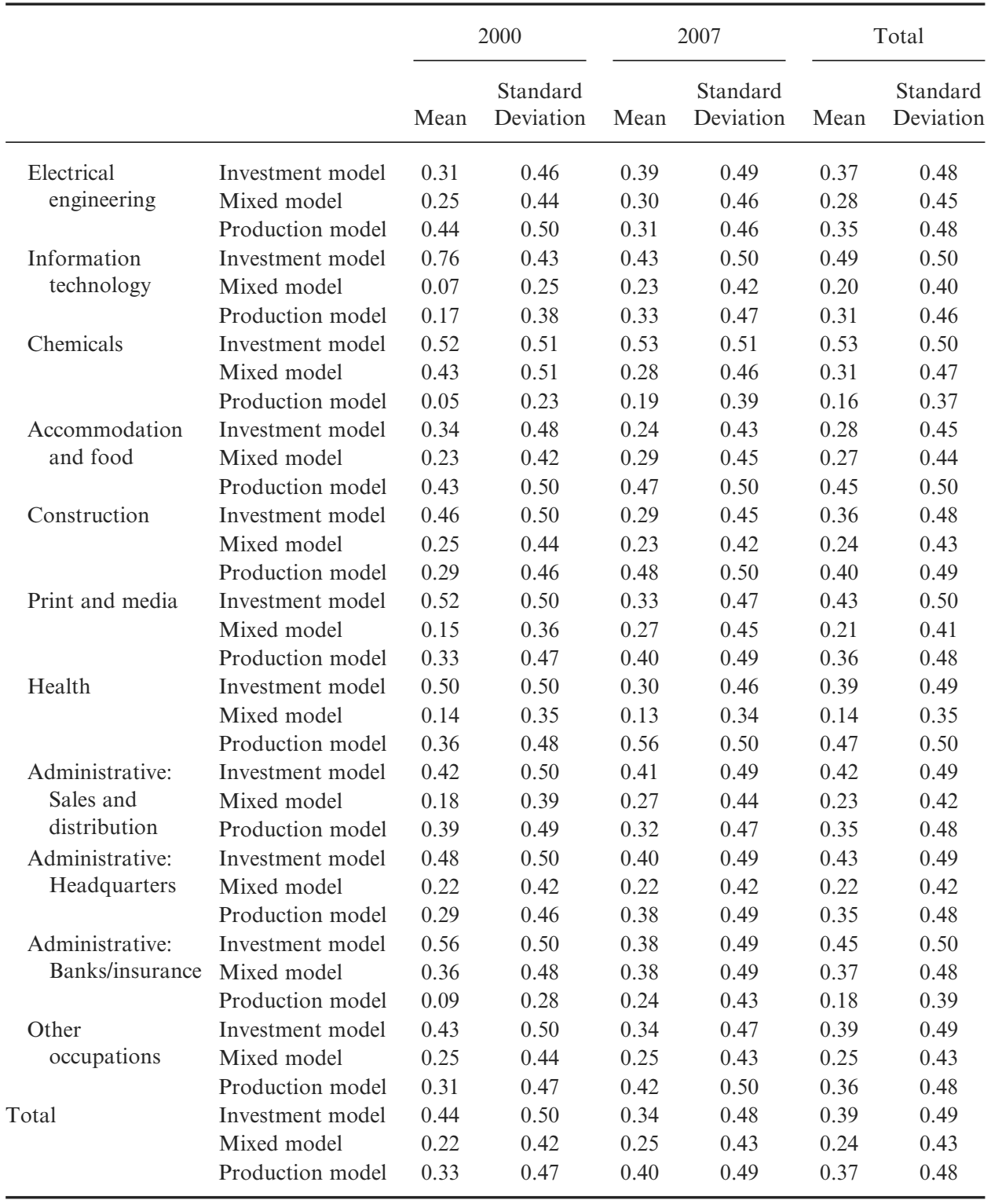

Source: BIBB Cost-Benefit Surveys 2000 and 2007. 